\title{
Effect of glucagon and pentagastrin on gastric mucosal potential difference in man $^{1}$
}

\author{
A. TARNAWSKI, K. J. IVEY, J. E. McGUIGAN, AND J. ENGLAND
}

From the Departments of Medicine, Harry S. Truman Memorial Veterans Hospital and University of Missouri, Columbia, Missouri, and the University of Florida College of Medicine, Gainesville, Florida, USA

SUMMARY Glucagon given as an intravenous injection of $2 \mathrm{mg}(0.57 \mathrm{mmol})$ or as a constant intravenous infusion of $1.64 \mu \mathrm{g} / \mathrm{kg} / \mathrm{h}(0.47 \mathrm{nmol} / \mathrm{kg} / \mathrm{h})$ significantly increased gastric mucosal potential difference (PD) in man. Pentagastrin infusion of $2 \mu \mathrm{g} / \mathrm{kg} / \mathrm{h}(2 \cdot 8 \mathrm{nmol} / \mathrm{kg} / \mathrm{h})$ dramatically reduced gastric PD in man. The effect of each of these hormones on PD was reversed by the administration of the other. Changes in PD induced by one hormone were not associated with reductions in blood levels of the other. There was an approximate correlation between changes in PD and pH of gastric aspirates, however, the patterns of PD and pH changes were at times dissimilar. This study indicates that administration of gastrointestinal hormones significantly alters gastric mucosal PD in man.

Few studies of the effect of gastrointestinal hormones on gastric mucosal potential difference (PD) in man or in animals have been reported (Andersson and Grossman, 1966; Vaughan et al., 1967). In one study, crude gastrin was reported to decrease PD by a mean of $5 \mathrm{mV}$ in the anaesthestised rat (Vaughan et al., 1967) but the decrease in PD was not invariable. In a study of the effects of secretin (an inhibitor of gastric acid secretion) on the gastroduodenal PD profile in man (Andersson and Grossman, 1966) no significant changes in PD across the oxyntic glandular area of the stomach were reported.

The present study was designed to determine and compare the effect of the acid inhibitory hormone glucagon and that of the acid stimulator pentagastrin on gastric mucosal PD in man.

\section{Methods}

This study which was approved by the institutional Human Experimentation Committee, was performed on 18 healthy male volunteers, aged 21 to 27 years. All subjects studied had a fasting pH value of 3.0 or less.

Studies were performed on three groups, each of six subjects, to examine the following effects: group 1

${ }^{1}$ This work was supported in part by the Medical Research Service of the Veterans Administration. We gratefully acknowledge the assistance and patient care facilities of the Clinical Research Center, University of Missouri, Columbia, Missouri. The paper was presented in part at the Annual Meeting of the Western Federation for Clinical Research, February 1977.

Received for publication 17 July 1978
- glucagon given as a single intravenous injection of $2 \mathrm{mg}(0.57 \mathrm{mmol})$ within three minutes; group 2pentagastrin administered as a constant intravenous infusion of $2 \mu \mathrm{g} / \mathrm{kg} / \mathrm{h}(2 \cdot 8 \mathrm{nmol} / \mathrm{kg} / \mathrm{h})$; and group 3glucagon given by constant intravenous infusion of $1.64 \mu \mathrm{g} / \mathrm{kg} / \mathrm{h} \quad(0.47 \mathrm{nmol} / \mathrm{kg} / \mathrm{h})$. To examine the interrelationships of glucagon and pentagastrin on $P D$, in group $2(n=6)$ constant pentagastrin infusion $(2 \mu \mathrm{g} / \mathrm{kg} / \mathrm{h})$ was discontinued after 60 minutes of infusion and followed by a single $2 \mathrm{mg}$ intravenous glucagon injection; this was followed in 15 minutes by constant infusion of pentagastrin $2 \mu \mathrm{g} / \mathrm{kg} / \mathrm{h}$. In group $3(\mathrm{n}=6)$, a constant infusion of glucagon was administered for 60 minutes and was then followed by a constant pentagastrin infusion of $2 \mu \mathrm{g} / \mathrm{kg} / \mathrm{h}$ for 30 minutes.

Parameters measured were: (1) gastric mucosal PD recorded continuously as previously described using intragastric and peripheral vein $\mathrm{KC1}$-in-agar electrodes (Ivey et al., 1975); a 30 minute baseline period was achieved with saline before drug administration. (2) $\mathrm{pH}$ of gastric aspirates obtained at 30 minute intervals and determined with a Beckman Expandometric $\mathrm{pH}$ meter. The $\mathrm{pH}$ was measured directly with a glass electrode. Conversion to hydrogen ion concentration was done by the table of Moore (1968) based on the sodium and potassium concentration of the gastric juice. $\mathrm{Na}^{+}$and $\mathrm{K}^{+}$concentrations were read on an (IL) Instrumentation Laboratory, Inc. flame photometer. In three subjects, studies were repeated after pentagastrin infusion (group 2) so that gastric aspirates could be obtained at five and $15 \mathrm{~min}$ utes after beginning the pentagastrin infusion. In an 1116 
additional two subjects in group 2 , a $\mathrm{pH}$ profile was obtained by continuous recording after pentagastrin injections by use of an intragastric $\mathrm{pH}$ probe (Beckman 151960, Cecar Micro-combination pH electrode). These last five additional studies were done separately so that accurate $\mathrm{pH}$ readings could be obtained without mechanical or electrical interference with the PD recordings. The $\mathrm{pH}$ values of these five subjects at five and 15 minutes after onset of pentagastrin infusion are shown by aster isks in Fig. 2. The doses of pentagastrin used as as infusion $2.0 \mu \mathrm{g} / \mathrm{kg} / \mathrm{h}$, and of glucagon as a single injection of $2 \mathrm{mg}$ are similar to those used by Christiansen and Hendel (1973) in their study of interreactions of these two drugs on acid secretion and inhibition, except that these workers used $1.5 \mu \mathrm{g} / \mathrm{kg} / \mathrm{h}$ pentagastrin. The dose of $2.0 \mu \mathrm{g} / \mathrm{kg} / \mathrm{h}$ was chosen, as this more closely resembled the dose of pentagastrin 2.0 $\mu \mathrm{g} / \mathrm{kg} / 40$ minutes, found by dose response curve to cause a maximal acid secretory response with continuous intravenous infusion (Prugh et al., 1975).

Levels of plasma glucagon and serum gastrin in group 1 and of glucagon and pentagastrin in group 2 were estimated as $\mathrm{pg} / \mathrm{ml}$ or $\mathrm{pmol} / \mathrm{l}$, using standard radioimmunoassay methods (McGuigan and Trudeau, 1970; Faloona and Unger, 1974). The glucagon levels were estimated using Unger's $30 \mathrm{~K}$ glucagon antiserum highly specific for pancreatic glucagon (Faloona and Unger, 1974). The pentagastrin levels $(\mathrm{pg} / \mathrm{ml}$ and $\mathrm{pmol} / \mathrm{l})$ were determined using antibodies to the carboxyl terminal tetrapeptide amide conjugated to bovine serum albumin as immunogen, with pentagastrin as the reference material (McGuigan and Trudeau, 1970). Therefore, these results are expressed as $\mathrm{pmol} / \mathrm{l}(\mathrm{pg} / \mathrm{ml})$ pentagastrin, are authentic for this compound, and do not represent immunological cross-reactivity with antibodies to the heptadecapeptide, but rather direct measurements of pentagastrin levels.

Results obtained were analysed statistically using paired and unpaired Student's $t$ tests respectively.

\section{Results}

Figure 1 shows the effect of a single intravenous injection of glucagon on gastric mucosal PD. PD rose rapidly over 20 minutes from basal (mean \pm SE) $-48 \pm 2 \mathrm{mV}$ to $-64 \pm 2 \mathrm{mV} \quad(\mathrm{P}<0.001)$. A significant rise in gastric PD $(P<0.001)$ persisted for 120 minutes after injection. During this time, gastric $\mathrm{pH}$ also increased. The reduction in hydrogen ion concentration from baseline $20 \pm 2 \mathrm{mmol} / 1$ to $2.0 \pm 0.5 \mathrm{mmol} / \mathrm{l}$ was significant at all time periods $(\mathrm{P}<0.01)$.

Figure 2 shows the effect of continuous intravenous infusion of pentagastrin on PD. At the end of one

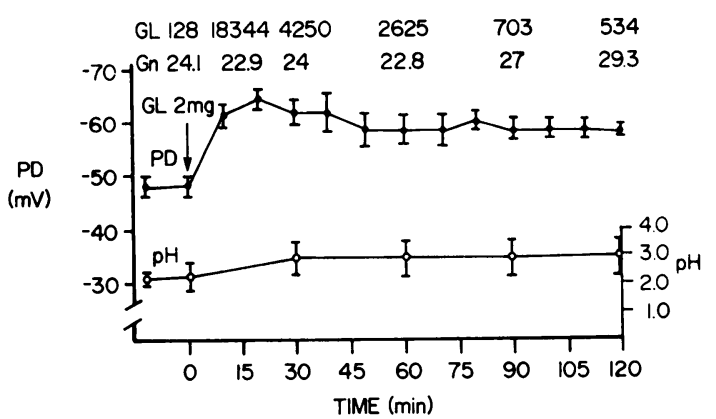

Fig. 1 Effect of glucagon injection (GL) on gastric $P D$ and $p H$. Values for $P D$ and $p H$ in this and subsequent figures are mean \pm standard error. In this and subsequent figures $P D$ is expressed on the vertical axis as negative millivolts. In the text an increase in electronegativity is termed a 'rise' in $P D$ and a decrease a 'fall' in PD. Mean values for serum glucagon and gastrin in $\mathrm{pg} / \mathrm{ml}$ during the study are shown above the $P D$ and $p H$ curves.

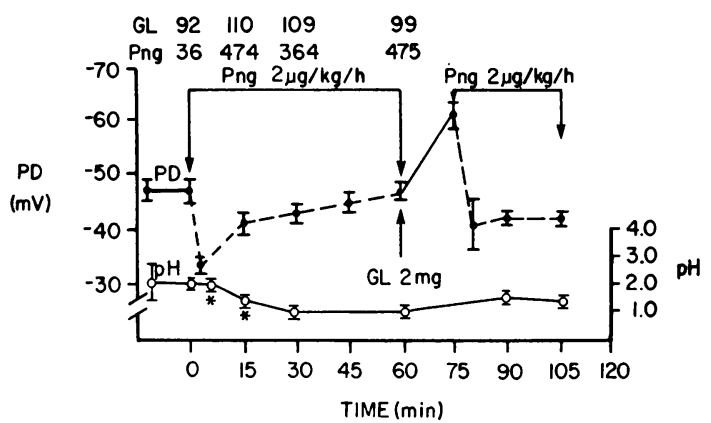

Fig. 2 Effect of pentagastrin (PNG) infusion on gastric $P D$ and $p H$. Asterisks $\left({ }^{*}\right)$ refer to $p H$ values obtained in five subjects studied separately to obtain values at five and 15 minutes, see text. Mean values for plasma glucagon and pentagastrin (in $\mathrm{pg} / \mathrm{ml}$ ) during the study are shown above the $P D$ and $p H$ curves.

hour the pentagastrin infusion was followed by a single injection of glucagon. Fifteen minutes later the pentagastrin infusion was started again. The figure shows a highly significant $(P<0.001)$ fall in PD within three minutes of starting pentagastrin; at the end of one hour glucagon injection caused a significant $(P<0.01)$ rise in PD. Reinfusion of pentagastrin again caused a highly significant fall in $\mathrm{PD}(\mathrm{P}<0.001)$ Figure 2 also illustrates some of the relationships between changes in PD and gastric $\mathrm{pH}$. Initiation of pentagastrin infusion was followed by a dramatic drop in PD within 3.5 minutes. In five subjects restudied with pentagastrin infusion specifically to measure immediate effects on gastric $\mathrm{pH}$, there was no detectable fall in $\mathrm{pH}$ at five minutes. In two of 
these subjects, intragastric $\mathrm{pH}$ was monitored continuously after pentagastrin injection by a $\mathrm{pH}$ probe. In neither subject was a decrease in PD recorded within the first five minutes of injection. The pH profile by continuous recording closely resembled that shown in Fig 2. In all subjects, the increase in hydrogen ion concentration after pentagastrin (reduction of $\mathrm{pH}$ ) was significantly raised at 30 and 60 minutes. It should also be noted that, in the first 30 minutes after pentagastrin injection while gastric pH was still falling, gastric PD had recovered significantly $(P<0.01)$. At 30 and 60 minutes after pentagastrin infusion gastric $\mathrm{pH}$ was still maximally reduced, but gastric PD was returning toward or had returned to baseline.

Figure 3 shows the effect of glucagon infusion on gastric PD. A similar rise in PD occurred as with the injection (from $-42 \pm 1.5 \mathrm{mV}$ to $-58 \pm 3 \mathrm{mV}$, $P<0.001)$ though the peak rise was delayed to 45 minutes. Pentagastrin infusion was followed by a marked fall in PD within three minutes from $(-58 \pm 3 \mathrm{mV}$ to $-34 \pm 1 \mathrm{mV}, \mathrm{P}<0.001)$. While the mean gastric $\mathrm{pH}$ was raised after glucagon infusion the change in hydrogen concentration failed to achieve statistical significance. The fall in hydrogen concentration after the onset of pentagastrin infusion was significant $(\mathrm{P}<0.01)$.

Glucagon injection induced significant hyperglucagonaemia (Table 1), but did not change serum

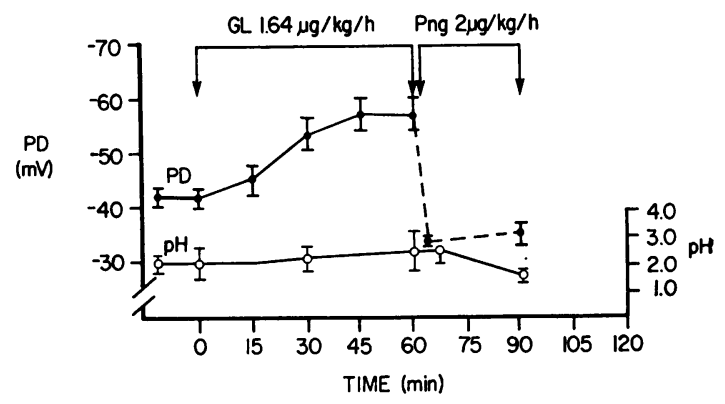

Fig. 3 Effect of glucagon infusion (GL) alone and followed by pentagastrin infusion on gastric $P D$ and $p H$.

gastrin levels significantly. Pentagastrin infusion was followed by persistent hyperpentagastrinaemia, but was not associated with significant changes in plasma glucagon levels (Table 2). Comparison of plasma glucagon values (Table 1) during the period of significantly raised PD (Fig. 1) indicates that a significant rise in PD is maintained throughout the period of hyperglucagonaemia, including the two hour levels of $534 \mathrm{pg} / \mathrm{ml}(1861 \mathrm{pmol} / \mathrm{l})$. This value is not far above blood glucagon levels observed after a meal $(190$ to $426 \mathrm{pg} / \mathrm{ml}$ or 660 to $1485 \mathrm{pmol} / \mathrm{l})$ by Christiansen et al. (1976), which suggests that glucagon may affect PD at physiological levels.

Table 1 Blood hormone levels after intravenous injection of $2 \mathrm{mg}(573 \mu \mathrm{mol})$ glucagon (Mean $\pm S E)$

\begin{tabular}{|c|c|c|c|c|c|c|}
\hline & \multicolumn{6}{|c|}{ Time (minutes) } \\
\hline & 0 & 15 & 30 & 60 & 90 & 120 \\
\hline $\begin{array}{l}\text { Plasma glucagon } \\
\mathrm{pg} / \mathrm{ml} \\
\mathrm{pmol} / \mathrm{l}\end{array}$ & $\begin{array}{l}128 \pm 7 \\
446 \pm 24\end{array}$ & $\begin{array}{r}18,344 \pm 1300^{*} \\
63929 \pm 4531^{*}\end{array}$ & $\begin{array}{l}4,250 \pm 990^{*} \\
14811 \pm 3450^{*}\end{array}$ & $\begin{array}{l}2,625 \pm 730^{*} \\
9148 \pm 2544^{*}\end{array}$ & $\begin{array}{r}703 \pm 110^{*} \\
2450 \pm 383^{*}\end{array}$ & $\begin{array}{r}534 \pm 68^{*} \\
1861 \pm 237^{*}\end{array}$ \\
\hline $\begin{array}{l}\text { Serum gastrin } \\
\mathrm{pg} / \mathrm{ml} \\
\mathrm{pmol} / \mathrm{l}\end{array}$ & $\begin{array}{l}24 \cdot 1 \pm 2 \cdot 0 \\
52 \cdot 5 \pm 4 \cdot 4\end{array}$ & $\begin{array}{l}22.9 \pm 2.0 \\
49.9 \pm 4.4\end{array}$ & $\begin{array}{r}24 \pm 2 \cdot 3 \\
52 \cdot 3 \pm 5 \cdot 0\end{array}$ & $\begin{array}{l}22 \cdot 8 \pm 2 \cdot 3 \\
49 \cdot 7 \pm 5 \cdot 0\end{array}$ & $\begin{array}{l}27 \cdot 0 \pm 2 \cdot 0 \\
58 \cdot 8 \pm 4 \cdot 4\end{array}$ & $\begin{array}{l}29 \cdot 3 \pm 2 \cdot 3 \\
63 \cdot 8 \pm 5 \cdot 0\end{array}$ \\
\hline
\end{tabular}

${ }^{*} \mathrm{P}<0.001$ vs $\mathbf{0}$ value. Units are expressed in terms of conventional units $\mathrm{pg} / \mathrm{ml}$, and SI units $\mathrm{pmol} / \mathrm{l}$.

Table 2 Blood hormone levels after constant intravenous infusion of $2 \mu \mathrm{g} / \mathrm{kg} / \mathrm{h}(2 \cdot 8 \mathrm{nmol} / \mathrm{kg} / \mathrm{h})$ Pentagastrin $($ Mean $\pm S E)$

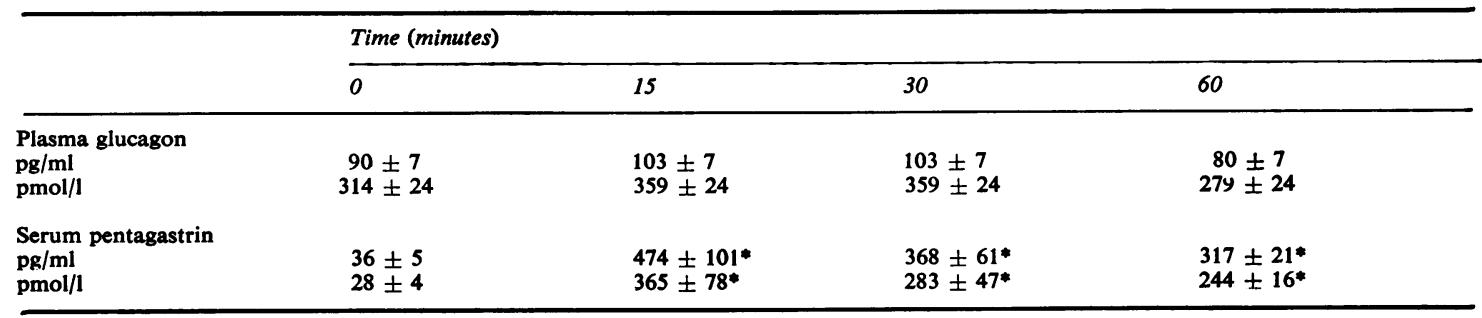

$*_{P}<0.005$ vs 0 value. 


\section{Discussion}

This study showed that, in the doses used, administration of glucagon increases and pentagastrin significantly reduces gastrin PD. The effect evoked by each of these hormones was reversed by the other. A marked and significant increase in gastric PD occurred after constant intravenous infusion of glucagon in a dose of $1.64 \mu \mathrm{g} / \mathrm{kg} / \mathrm{h}(0.47 \mathrm{nmol} / \mathrm{kg} / \mathrm{h})$. This dose has been reported as near physiological (Christiansen et al., 1976). It suggests that glucagon affects PD at physiological levels. Unfortunately, as we did not measure plasma glucagon levels during glucagon infusion at this dose, we cannot say whether plasma glucagon was at a physiological level or not in our subjects. While the studies reported herein with pentagastrin were not within the physiological range, in very recent studies (Ivey et al., 1978) by infusing human gastrin I we have found a significant fall in PD with a serum gastrin level well within the physiological range $(85 \pm 30 \mathrm{pg} / \mathrm{ml} ; 185 \pm 64$ $\mathrm{pmol} / \mathrm{l})$.

At the hormone doses used in our studies, neither glucagon nor pentagastrin infusion significantly altered blood gastrin or glucagon levels respectively. These results make it unlikely that the effects of either hormone on PD were mediated through changes in blood levels of the other.

Pentagastrin increases acid secretion, whereas glucagon inhibits basal and pentagastrin stimulated gastric acid output (Christiansen and Hendel, 1973; Christiansen et al., 1976). It is possible that the effects of these hormones on PD are direct reflections of their actions on gastric acid secretion by formation of liquid-junction potentials between secreted acid and luminal contents. According to this hypothesis, agents which increase gastric acid secretion cause a decrease in PD, while those which inhibit gastric acid secretion cause an increase in PD. This hypothesis cannot be correct, as certain inhibitors of gastric acid secretion-for example, the orally effective prostaglandin 16 16-dimethyl $\mathrm{PGE}_{2}$-cause a fall in PD (Bolton and Cohen, 1976; Dajani et al., 1978). Moreover, such a hypothesis must take into account that the change in PD after intravenous pentagastrin infusion in our study was dramatic and prompt, reaching its peak at 3.5 minutes after starting infusion (Fig. 2). In this period, no changes in the $\mathrm{pH}$ of gastric luminal contents were detected even with continuous recording using a pH probe. Subsequently, in our study PD gradually recovered while gastric $\mathrm{pH}$ decreased, so the pattern of $\mathrm{pH}$ and $\mathrm{PD}$ changes was different (Fig. 2). The rise in PD with onset of acid secretion probably reflects the known ability of intragastric acid to raise gastric PD in man (Ivey et al., 1976; Ivey and MacKercher, 1977).
Further evidence against formation of liquidjunction potentials as the sole explanation of the effect of these gastrointestinal hormones on PD would be evidence of similar effects on PD in tissues which cannot secrete acid. In a separate study (Tarnawski et al., 1977) in rats, we have found that pentagastrin causes the same reduction in PD in ligated forestomach (non-acid secreting mucosa) pouches as in the gastric fundus (acid secreting mucosa). In the human colon, pentagastrin has significantly increased the number of spike potentials (Snape et al., 1977). Such studies indicate that the effect of gastrointestinal hormones on PD does not simply reflect effects on pH. Effects such as modification of active ion transport and permeability of the mucosa to passive ionic diffusion (Cohen, 1974) should be considered.

In piglets, Forte et al. (1977) reported definite reduction of electrical $P D$ and resistance within 30 seconds of histamine administration, whereas $\mathrm{H}^{+}$ secretion was first observed four to five minutes after the secretagogue was given. They postulated that the fall in PD and resistance was due to increased apical surface area in the parietal cells as a result of proliferation of secretory canaliculi. In unpublished studies we have found by morphometric analysis that pentagastrin causes the same increase in canalicular surface area at the time of fall in PD in man and before detectable change in $\mathrm{pH}$. On the other hand, glucagon injection significantly decreases canalicular membrane area at the time PD is increased (Ackman et al., 1978).

In conclusion, pentagastrin and glucagon exert marked and significant effects on gastric mucosal PD in man. The physiological importance of this effect and its mechanism remain to be established.

\section{References}

Ackman, K., Tarnawski, A., Ivey, K. J., Sherman, D., and Krause, W. (1978). The effects of glucagon on the ultrastructure of parietal cells in man (Abstract). Gastroenterology, 74, 1002.

Andersson, S., and Grossman, M. I. (1966). Effects of histalog and secretin on gastroduodenal profile of $\mathrm{pH}$, potential difference, and pressure in man. Gastroenterology, 51, 10-17.

Bolton, J. P., and Cohen, M. M. (1976). Permeability effects of $E_{2}$ prostaglandins on canine gastric mucosa (Abstract). Gastroenterology, 70, 865.

Christiansen, J., and Hendel, L. (1973). The effect of glucagon on pentagastrin-induced gastric acid secretion and serum calcium concentration in man. Scandinavian Journal of Gastroenterology, 8, 81-84.

Christiansen, J., Holst, J. J., and Kalaja, F. (1976). Inhibition of gastric acid secretion in man by exogenous and endogenous pancreatic glucagon. Gastroenterology, 70, 688-692.

Cohen, M. M. (1974). Increased gastric mucosal permeability during active secretion in humans. Surgical Forum, 25, 404-406. 
Dajani, E. Z., Callison, D. A., and Bertermann, R. E. (1978). Effects of E-prostaglandins on canine gastric potential difference. American Journal of Digestive Diseases, 23, 436-442.

Faloona, G. R., and Unger, R. H. (1974). Glucagon. In Methods of Hormone Radioimmunoassay, pp. 317-330. Edited by B. M. Jaffe and H. R. Behrman. Academic Press: New York.

Forte, T. M., Machen, T. E., and Forte, J. G. (1977). Ultrastructural changes in oxyntic cells associated with secretory function: a membrane-recycling hypothesis. Gastroenterology, 73, 941-955.

Ivey, K. J., Baskin, W. N., and Jeffrey, G. E. (1975). Effect of cimetidine on gastric potential difference in man. Lancet, 2, 1072-1073.

Ivey, K. J., Krause, W., MacKercher, P., Baskin, W., Jeffrey, G. E., and Burks, M. (1976). Effect of acid on aspirin-induced ultrastructural and potential difference changes in human gastric mucosa. Clinical Research, 24, 287A.

Ivey, K. J., and MacKercher, P. A. (1978). Effect of cimetidine on ion fluxes and potential difference across the human stomach. Gut, 19, 414-418.

Ivey, K. J., Tarnawski, A., and McGuigan, J. (1978). Effect of physiological level of human gastrin on gastric potential difference in man (Abstract). Gastroenterology, 74, 1047.

McGuigan, J. E., and Trudeau, W. L. (1970). Studies with antibodies to gastrin: radioimmunoassay in human serum and physiological studies. Gastroenterology, 58, 139-150.

Moore, E. W. (1968). Determination of pH by the glass electrode: pH meter calibration for gastric analysis. Gastroenterology, 54, 501-507.

Prugh, M. F., Schorr, B. A., Vlahcevic, Z. R., and Makhlouf, G. M. (1975). Intravenous pentagastrin as a partial agonist of gastric secretion in man: evidence in favor of the existence of hormonal inhibitory sites. Gastroenterology, 68, 45-49.

Snape, W. J. Jr., Carlson, G. M., Cohen, S. (1977). Human colonic myoelectric activity in response to prostigmin and the gastrointestinal hormones. American Journal of Digestive Diseases, 22, 881-887.

Tarnawski, A., Krause, W., and Ivey, K. J. (1977). Drop in gastric potential difference after pentagastrin: unrelated to oxyntic cell stimulation? (Abstract). Gastroenterology, 72, 1139.

Vaughan, B. E., Ridley, H. A., and Cummins, J. T. (1967). Transmural potential and stimulated acid in innervated, rat stomach perfused at $\mathrm{pH} 3 \cdot 0$. American Journal of Physiology, 213, 651-656. 